\title{
Endoscopic Septoturbinoplasty among Patients Undergoing Surgery in the Department of Otolaryngology-Head and Neck of a Tertiary Care Hospital: A Descriptive Cross-sectional Study
}

\author{
Nain Bahadur Mahato, ${ }^{1}$ Meera Bista, ${ }^{1}$ Bhuwan Bhandari, ${ }^{2}$ Rosi Pradhan ${ }^{3}$ \\ 'Department of Otolaryngology-Head and Neck Surgery, Kathmandu Medical College and Teaching Hospital, \\ Sinamangal, Kathmandu, Nepal, '2Department of Surgery, Nepal National Hospital, Kalanki, Kathmandu, Nepal, \\ ${ }^{3}$ Department of Anaesthesia and Critical Care, KIST Medical College, Imadol, Lalitpur, Nepal.
}

\begin{abstract}
Introduction: Septoplasty without turbinoplasty is one of the main reasons for failure of procedure in case of deviated nasal septum with inferior turbinate hypertrophy. Septoturbinoplasty is the procedure of choice for complete treatment. The main objective is to find out the prevalence of endoscopic septoturbinoplasty among patients undergoing surgery in Department of Otolaryngology-Head and Neck of a tertiary care hospital.

Methods: This was a descriptive cross-sectional study in Department of Otolaryngology-Head and Neck Surgery done over a period of 1 year duration from 1st August 2020 to 31st July 2021 among 1248 patients who underwent surgery in the department. Ethical Approval was taken from Institutional Review Committee of Kathmandu Medical College and Teaching Hospital (Reference number: 2207202004). A convenience sampling technique was used. Two different techniques, Microdebrider Assisted Turbinoplasty and Out-fracture with Submucosal Diathermy were used in surgery. Nasal Obstruction and Symptom Evaluation Scale questionnaire was used pre and postoperatively for data collection. Data were analyzed in Statistical Package for the Social Sciences version 16. Point estimate at $95 \%$ Confidence Interval was calculated, with frequency, percentage, mean and standard deviations.
\end{abstract}

Results: Out of 1248 patients, about 92 (7.37\%) patients (4.95-10.14 at 95\% Confidence Interval) underwent septoturbinoplasty. The mean Nasal Obstruction and Symptom Evaluation Scale before surgery was $75.21 \pm 6.19$

Conclusions: The prevalence of septoturbinoplasty in our study is similar to other studies done in similar settings. We found almost complete resolution of breathing problems following endoscopic septoturbinoplasty, hence improving quality of life.

Keywords: endoscopy; Nepal; septoplasty; surgery; turbinoplasty.

\section{INTRODUCTION}

Nasal obstruction negatively affects patients' quality of life (QOL). ${ }^{1-3}$ Sustained nasal obstruction may be due to deviation of the nasal septum (DNS) associated with compensatory hypertrophy of inferior turbinate (ITH). ${ }^{4}$ Septoturbinoplasty is a corrective surgical procedure done to straighten a deviated nasal septum along with reduction in size of turbinates. The most common cause of septoplasty failure is inferior turbinate hypertrophy (ITH) that is not treated properly. ${ }^{5}$
Several techniques have been described for the correction of inferior turbinate hypertrophy such as total or partial turbinectomy, submucosal diathermy, microdebrider assisted turbinoplasty, out fracture, radiofrequency, laser therapy etc. ${ }^{6-9}$ Despite the

\footnotetext{
Correspondence: Dr. Nain Bahadur Mahato, Department of Otolaryngology-Head and Neck Surgery, Kathmandu Medical College and Teaching Hospital, Sinamangal, Kathmandu, Nepal. Email: nain_boldly@hotmail. com, Phone: +977-9851199191.
} 
increasing number of surgical procedures turbinoplasty, out fracture, and bipolar cautery methods are frequently in use for the last three decades. ${ }^{10}$

The main objective is to find out the prevalence of endoscopic septoturbinoplasty among patients undergoing surgery in Department of OtolaryngologyHead and Neck of a tertiary care center.

\section{METHODS}

This was a descriptive cross-sectional study in the department of Otolaryngology-Head and Neck Surgery (HNS) of Kathmandu Medical College and Teaching Hospital (KMCTH) over a period of one year duration from 1st August 2020 to 31 st July 2021 AD. Ethical Approval was taken from the Institutional Review Committee of KMCTH (Reference number: 2207202004). All the patients who gave consent for the surgery were included in our study and who did not give the consent were excluded from the study. Patients having symptomatic deviated nasal septum with compensatory hypertrophy of inferior turbinates seeking septoturbinoplasty were included in our study. Patients with septal perforations, nasal polyposis, acute or chronic rhinosinusitis, concha bullosa, previous nasal or paranasal surgery and granulomatous diseases such as tuberculosis, syphilis, Wegener's granulomatosis were excluded from the study, also the patients who did not give the consent were excluded. A convenience sampling technique was used.

Sample size was calculated using the formula:

$$
\begin{aligned}
\mathrm{n} & =\mathrm{Z}^{2} \times \mathrm{p} \times \mathrm{q} / \mathrm{e}^{2} \\
& =(1.96)^{2} \times 0.5 \times 0.5 /(0.03)^{2} \\
& =1068
\end{aligned}
$$

Where,

$\mathrm{n}=$ minimum required sample size

$Z=1.96$ at $95 \%$ Confidence Interval $(\mathrm{Cl})$

$p=50 \%$ prevalence taken for maximum sample size calculation

$q=1-p$

$\mathrm{e}=$ margin of error, $3 \%$

Hence, the calculated sample size was 1068 . However, we included 1248 patients.

Adding $10 \%$ missing data rate, the calculated sample size was 1175 . However, 1248 samples were taken.

All the patients to be enrolled in the study group were examined by a consultant Ear, Nose, and Throat (ENT) surgeon. History regarding the cause of nasal obstruction either congenital or traumatic was taken. Diagnostic Nasal Endoscopy (DNE) using Fiberoptic Laryngoscopy (FOL) was done to find out the type and grade of deviated nasal septum (DNS) and to rule out any other endonasal pathology other than ITH. NOSE scale ${ }^{11}$ questionnaire comprising 5 questions and each question having five options between 0 and 4 was used for data collection. For all 5 questions the total score was calculated and the result was divided by 20 and multiplied by 100 (Zero represents no problem and 100 severe problems). The questions were asked to only those patients who had undergone septoturbinoplasty. The questionnaire was converted into both Nepalese and English version. The questions were asked as an interview so as to give maximum comfort to the patients. The patients were taught how to score the questionnaire in the postoperative period for data collection.

Two different techniques, Microdebrider Assisted Turbinoplasty and Out-fracture with Submucosal Diathermy were used. For the surgical procedure, informed written consent was taken from the patient and patient parties. The procedure was done under general anesthesia. Septoplasty with quilting suture on the septum was done in all the cases followed by reduction of ITH.

Microdebrider Assisted Turbinoplasty was performed to reduce the size of bulky inferior turbinate intraturbinally under endoscopic guidance. A submucosal pocket was dissected by tunneling with freer's elevator and microdebrider blade with dissecting tip in an anterior to posterior and superior to inferior sweeping motion. A $2.9 \mathrm{~mm}$ diameter microdebrider tip (Medtronic Xomed ${ }^{\circledR}$ ), rotating continuously in a circular fashion was set at 3,000 rpm while using suction irrigation, was applied to remove all the stromal tissue from inside of the turbinate with preservation of the mucosal flap. For the reduction of hypertrophied posterior end (tails), a second entry point was made at the mid-portion of the inferior turbinate to gain better access to treat the "mulberry-tip" of the inferior turbinate.

Similarly, Out-fracture and Submucosal Diathermy techniques were also used. Under endoscopic guidance, out-fracture of inferior turbinate was done by the use of Freer's elevator on both sides and then a $3-4 \mathrm{~mm}$ mucosal incision was made on the head of the inferior turbinate. The tunnel was created on the medial surface and inferior edge of the bone by the use of freer's elevator. The excess submucosal and cavernous tissue was cauterized by using bipolar electrocautery forceps set at the power of $35-45 \mathrm{~W}$ in the posterior to anterior direction.

After completion of the surgery, internal nasal packing was done with merocele in $35(38 \%)$ patients for 1 day. The average time taken for septoturbinoplasty was around 55 minutes. All the patients were admitted for 1 day and internal nasal packs were removed during discharge time. Routine follow up was done on 7th, 15 th, 30th, and 60th day postoperatively to find out 
Mahato et al. Endoscopic Septoturbinoplasty among Patients Undergoing Surgery in The Department of Otolaryngology-Head and Neck...

improvement in nasal obstruction using the NOSE scale.

Data was collected postoperatively and was analyzed using Statistical Packages for the Social Sciences version 16. Point estimate at $95 \%$ Confidence Interval was calculated, with frequency, percentage, mean and standard deviations.

\section{RESULTS}

Out of 1248 patients, about 92 (7.37\%) patients (4.95-10.14 at $95 \%$ Confidence Interval) underwent septoturbinoplasty using two different techniques. Regarding Turbinoplasty, 46 (50\%) patients were operated by using Microdebrider Assisted Turbinoplasty (MAT) technique and the rest of the 46 (50\%) by Outfracture with Submucosal Diathermy (SMD) technique. Among them, 51 (55.4\%) were male and 41 (44.6\%) were female with age ranging from $15-50$ years were enrolled in our study. Internal nasal packing was done with merocele in 35 (38\%) patients for 1 day.

The mean NOSE score before surgery was 75.21 \pm 6.19 . Likewise, the mean NOSE score after 1 week of surgery was $27.60 \pm 4.41$, after 2 weeks was $26.41 \pm 3.34$, after 1 month was $23.36 \pm 3.06$ and after 2 months was $20.10 \pm 3.14$ (Table 1, Figure 1).

\begin{tabular}{|c|c|c|c|}
\hline NOSE Score & Mean \pm SD & Minimum & Maximum \\
\hline Before surgery & $75.22 \pm 6.19$ & 60 & 90 \\
\hline $\begin{array}{l}1 \text { week after } \\
\text { surgery }\end{array}$ & $27.61 \pm 4.41$ & 20 & 40 \\
\hline $\begin{array}{l}2 \text { weeks after } \\
\text { surgery }\end{array}$ & $26.41 \pm 3.34$ & 20 & 35 \\
\hline $\begin{array}{l}1 \text { month after } \\
\text { surgery }\end{array}$ & $23.37 \pm 3.07$ & 15 & 30 \\
\hline $\begin{array}{l}2 \text { months after } \\
\text { surgery }\end{array}$ & $20.11 \pm 3.14$ & 10 & 25 \\
\hline
\end{tabular}

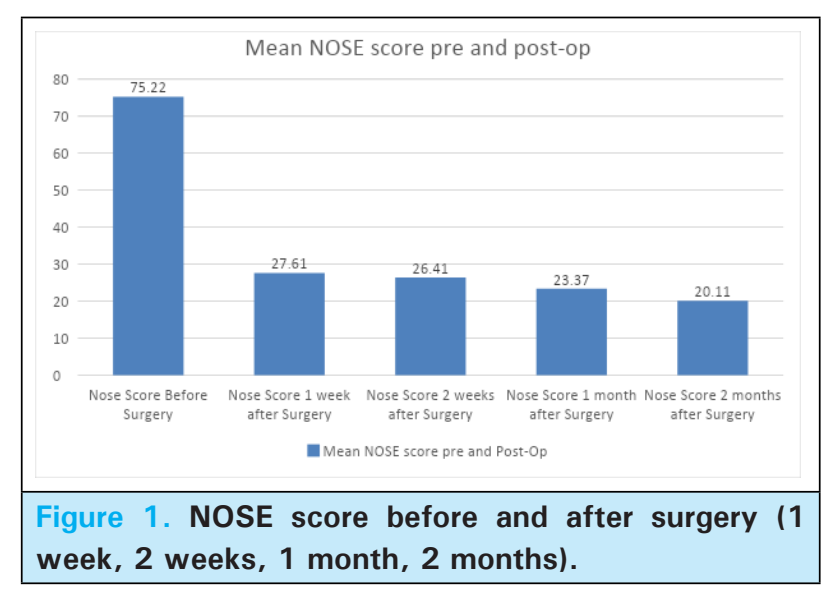

The mean NOSE score before and after surgery of both the techniques are shown in table 2 (Table 2).

\begin{tabular}{|lc|}
\hline \multicolumn{2}{|l|}{ Table 2. Mean NOSE score before and after surgery. } \\
\hline NOSE Score & Mean \pm SD \\
\hline Microdebrider Assisted Turbinoplasty & \\
Before surgery & $77.17 \pm 5.54$ \\
1 week after surgery & $26.74 \pm 4.11$ \\
2 weeks after surgery & $27.61 \pm 3.24$ \\
1 month after surgery & $23.69 \pm 3.24$ \\
2 months after surgery & $18.48 \pm 2.76$ \\
Submucosal Diathermy & \\
Before surgery & $73.26 \pm 6.25$ \\
1 week after surgery & $28.48 \pm 4.58$ \\
2 weeks after surgery & $25.22 \pm 2.97$ \\
1 month after surgery & $23.04 \pm 2.88$ \\
2 months after surgery & $21.74 \pm 2.63$ \\
\hline
\end{tabular}

\section{DISCUSSION}

Nasal obstruction is one of the commonest symptoms that patient presents in an ENT OPD. ${ }^{12} \mathrm{~A}$ large variety of diseases can cause different degree of nasal blockage, of which Inferior Turbinate Hypertrophy is one of the common causes. ${ }^{13}$ Deviated nasal septum and ITH have been the most common causes of nasal obstruction. Patients undergo Septoplasty as a management of deviated nasal septum yet they complain of nasal obstruction which is mostly due to unaddressed ITH. Most of the cases respond to antihistamines or local decongestant, however; surgery is needed if the ITH is due to submucous fibrosis rendering the turbinate incapable of decongestion. ${ }^{10}$ Septoturbinoplasty has an additive effect for the improvement of nasal obstruction. The basic principle of turbinoplasty is to reduce the turbinate size but the techniques differ from each other based on preservation of normal physiological function.

In our study we found that the mean NOSE score before surgery was 75.2 \pm 6.19 . Likewise, the mean NOSE score after 1 week of surgery was $27.60 \pm 4.41$, after 2 weeks was $26.41 \pm 3.34$, after 1 month was $23.36 \pm 3.06$ and after 2 months was $20.10 \pm 3.14$. Postoperatively all the patients reported improved symptom scores of nasal obstruction, nasal stuffiness, snoring, oral breathing and better health related quality of life (HQOL) which is similar to the study done by Nilsen, et al. ${ }^{14}$ In both the MAT and SMD groups, similar results on 7 th, 15 th and 30 th postoperative day was found, however on 60th postoperative day better results were seen in MAT group than out-fracture and SMD group. Similar results were seen in the study done by Joniau, et al. ${ }^{15}$ found that powered turbinoplasty was superior to submucosal cauterization in all aspects of the assessment.

Microdebrider Assisted Turbinoplasty (MAT) is relatively 
a new method for reducing the size of inferior turbinate. The complications associated with standard submucosal resection such as excessive resection of ITH, bleeding and crusting were largely avoided by MAT. In addition, this technique of turbinate reduction has been shown to be a reliable and safe method. ${ }^{16-18}$ Many authors used the microdebrider intraturbinally, few others used it extraturbinally for turbinate size reduction. We used a microdebrider intraturbinally to preserve the normal physiological function of mucosa. MAT is more difficult and has a higher complication rate than the out-fracture method, despite its high success rate. Inferior turbinate out-fracture and Submucosal Diathermy (SMD) is a safer and quickier technique, ${ }^{19}$ which we have used in $50 \%$ of our patients.

Our study showed $94 \%$ of the patients had complete resolution of nasal obstruction and stuffiness, while $6 \%$ of the patients had mild obstruction in 2 months followup in the MAT group. Similar study done by Friedman, et al. ${ }^{18}$ had found that symptoms of bilateral nasal obstruction and stuffiness were almost completely resolved after 6 weeks of MAT. Complete resolution of nasal blockage in $80 \%$ of patients and mild nasal obstruction in $20 \%$ of the patients two months after MAT was seen in the study done by Hegazy, et al. ${ }^{20}$ Mahlon, et al. performed MAT for 100 patients in the period from 1994 to 1997 and found that postoperative improvement in nasal patency occurred in $93 \%$ of the patients. ${ }^{21}$

We found $90 \%$ of the patients had complete resolution of nasal obstruction and stuffiness, while $10 \%$ of the patients had mild obstruction in 2 months followup in the Out-fracture and SMD group. Similar study done by Ehab, et al. ${ }^{22}$ found relief of nasal obstruction in $75 \%$ of the patients after one month of SMD and improvement of nasal patency was seen in all patients after three months. Fradis, et al. ${ }^{23}$ found that diathermy showed good results in $78 \%$ of cases two weeks after surgery. The efficacy of the procedure was reduced to $76 \%$ two months after surgery. Milo, et al. ${ }^{24}$ had found $70.3 \%$ experienced subjective improvement in nasal breathing after 2 months of SMD. Our results regarding improvement in nasal patency differ from the results obtained by other studies, these differences present because of out-fracture of inferior turbinate along with SMD in our study unlike only SMD in other studies.

The mean operative time for MAT was 30 minutes whereas that for SMD was 14 minutes; which is similar to the study done by Chen, et al. ${ }^{25}$ Diaa El Din, et al. ${ }^{26}$ found that intraoperative blood loss was $(37.1 \pm 7.4) \mathrm{ml}$ during MAT. We found $(50.2 \pm 4.2) \mathrm{ml}$ of intraoperative blood loss in both the techniques. Mucosal tears in MAT group were $13 \%$ and SMD group were $8 \%$ in our study which is similar to the study done by Liu, et al. ${ }^{27}$ noted $(11.7 \%)$ mucosal tears in the microdebrider group. We found $38 \%$ of our patients had postoperative crusting on 7 th day follow-up and was reduced to $2 \%$ on 2 months follow-up. Ehab, et al. ${ }^{22}$ found that crustation after SMD develops in $50 \%$ of patients in the first week, and this was reduced to $5 \%$ after 3 months. We found postoperative synaechiae in $(3.26 \%)$ of our patients. Similar study done by Friedman, et al. ${ }^{18}$ observed postoperative synaechiae in $5 \%$ of the patients while Liu, et al. ${ }^{27}$ observed postoperative crusting and synaechiae in $11.66 \%$ of the patients.

Since, the study is a descriptive cross-sectional study and done in single hospital, the findings of the study cannot be generalized to whole population.

\section{CONCLUSIONS}

The prevalence of septoturbinoplasty in our study is similar to other studies done in similar settings. We found almost complete resolution of breathing problems following endoscopic septoturbinoplasty, hence improving quality of life. Both the techniques are mucosal preservation techniques, but the results of MAT are more predictable in long term follow-up. Endoscopic guidance provided excellent visualization and intra-operative evaluation regarding the amount of turbinate tissue needed to be removed to achieve good patency and avoid complications.

\section{Conflict of Interest: None.}

\section{REFERENCES}

1. Han JK, Stringer SP, Rosenfeld RM, Archer SM, Baker DP, Brown SM, et al. Clinical Consensus Statement: Septoplasty with or without Inferior Turbinate Reduction. Otolaryngol Head Neck Surg. 2015 Nov;153(5):708-20. [․ubMed | Full Text | DOI]

2. Baumann I. Quality of life before and after septoplasty and rhinoplasty. GMS Curr Top Otorhinolaryngol Head Neck Surg. 2010;9:Doc06. [PubMed | Full Text | DOI]

3. Shedden A. Impact of nasal congestion on quality of life and work productivity in allergic rhinitis: findings from a large online survey. Treat Respir Med. 2005;4(6):439-46. [PubMed | Full Text | DOI]

4. Nurse LA, Duncavage JA. Surgery of the inferior and middle turbinates. Otolaryngol Clin North Am. 2009 Apr;42(2):295-309. [

5. Pollock RA, Rohrich RJ. Inferior turbinate surgery: an adjunct to successful treatment of nasal obstruction in 408 patients. Plast Reconstr Surg. 1984 Aug;74(2):227-36. [PubMed | Full $\underline{\text { Text] }}$ 
Mahato et al. Endoscopic Septoturbinoplasty among Patients Undergoing Surgery in The Department of Otolaryngology-Head and Neck...

6. Martinez SA, Nissen AJ, Stock CR, Tesmer T. Nasal turbinate resection for relief of nasal obstruction. Laryngoscope. 1983 Jul;93(7):871-5. [uㅏㄹed | Full Text | DOI]

7. Dawes PJ. The early complications of inferior turbinectomy. J Laryngol Otol. 1987 Nov;101(11):1136-9. [PubMed | Full $\underline{\text { Text }} \mid \underline{\mathrm{DOI}}]$

8. Puterman MM, Segal N, Joshua BZ. Endoscopic, assisted, modified turbinoplasty with mucosal flap. J Laryngol Otol. 2012 May;126(6):525-8. [라Med | Full Text | DOI]

9. Friedman N. Inferior turbinate reduction: an application for the microdebrider. Oper Tech Otolayngol Head Neck Surg. 2005;16(4):232-4. [Full Text | DOI]

10. Hol MK, Huizing EH. Treatment of inferior turbinate pathology: a review and critical evaluation of the different techniques. Rhinology. 2000 Dec;38(4):157-66. [PubMed | Full Text]

11. Stewart MG, Witsell DL, Smith TL, Weaver EM, Yueh B, Hannley MT. Development and validation of the Nasal Obstruction Symptom Evaluation (NOSE) scale. Otolaryngol Head Neck Surg. 2004 Feb;130(2):157-63. [․ㅏbMed | Full Text | DOI]

12. Mathai J. Inferior turbinectomy for nasal obstruction review of 75 cases. Indian J Otolaryngol Head Neck Surg. 2004 Jan;56(1):23-6. [PubMed | Full Text | DOI]

13. Hesham A, Badran H, Hussein A, Amin S, Salah M. Intraturbinal versus extraturbinal microdebrider-assisted inferior turbinoplasty: Preliminary results. Egypt J Ear Nose Throat Allied Sci. 2014 Mar;15(1):1-5. [Full Text | DOI]

14. Nilsen AH, Helvik AS, Thorstensen WM, Bugten V. A comparison of symptoms and quality of life before and after nasal septoplasty and radiofrequency therapy of the inferior turbinate. BMC Ear Nose Throat Disord. 2018 Jan 26;18:2. [PubMed | Full Text | DOI]

15. Joniau S, Wong I, Rajapaksa S, Carney SA, Wormald PJ. Long-term comparison between submucosal cauterization and powered reduction of the inferior turbinates. Laryngoscope. 2006 Sep;116(9):1612-6. [람ed | Full Text | DOI]

16. Yanez C. New technique for turbinate reduction in chronic hypertrophic rhinitis intraturbinal stroma removal using the microdebrider. Oper Tech Otolaryngol Head Neck Surg. 1998 Sep;9(3):135-7. [Full Text | DOI]

17. Gupta A, Mercurio E, Bielamowicz S. Endoscopic inferior turbinate reduction: an outcomes analysis. Laryngoscope. 2001 Nov;111(11):1957-9. [PubMed | Full Text | DOI]

18. Friedman M, Tanyeri H, Lim J, Landsberg R, Caldarelli D. A safe, alternative technique for inferior turbinate reduction. Laryngoscope. 1999 Nov;109(11):1834-7. [PubMed | Full Text | DOI]

19. Salam MA, Wengraf C. Concho-antropexy or total inferior turbinectomy for hypertrophy of the inferior turbinates? A prospective randomized study. J Laryngol Otol. 1993 Dec;107(12):1125-8. [ [PubMed | Full Text | DOI]

20. Hijazi HM, al-Badawi MR, Hassan AA. Endoscopic Submucous Inferior Turbinate Reduction with Microdebrider - A Study of 50 Case. In: Tanta Medical Sciences Journal. 2007 Mar;2(1):194-9. English, Arabic. [Full Text]

21. Van delden MR, Cook PR, Davis WE. Endoscopic partial inferior turbinoplasty. Otolaryngol Head Neck Surg. 1999 Oct;121(4):406-9. [PubMed | Full Text | DOI]

22. Yaseen TE. Thermal Reduction of Hypertrophied Inferior Turbinate. New Iraqi J Med. 2009;5(3):30-3. [Full Text]

23. Fradis M, Golz A, Danino J, Gershinski M, Goldsher M, Gaitini L, et al. Inferior turbinectomy versus submucosal diathermy for inferior turbinate hypertrophy. Ann Otol Rhinol Laryngol. 2000 Nov;109(11):1040-5. [람ed | Full Text $\mid \underline{\text { DOI] }}$

24. Fradis M, Malatskey S, Magamsa I, Golz A. Effect of submucosal diathermy in chronic nasal obstruction due to turbinate enlargement. Am J Otolaryngol. 2002 Nov-Dec;23(6):332-6. [람Med | Full Text | DOI]

25. Chen YL, Liu CM, Huang HM. Comparison of microdebrider-assisted inferior turbinoplasty and submucosal resection for children with hypertrophic inferior turbinates. Int J Pediatr Otorhinolaryngol. 2007 Jun;71(6):921-7. [PubMed | Full Text | DOI]

26. El Henawi Del D, Ahmed MR, Madian YT. Comparison between power-assisted turbinoplasty and submucosal resection in the treatment of inferior turbinate hypertrophy. ORL J Otorhinolaryngol Relat Spec. 2011;73(3):151-5. [PubMed | Full Text | DOI]

27. Liu CM, Tan CD, Lee FP, Lin KN, Huang HM. Microdebrider-assisted versus radiofrequency-assisted inferior turbinoplasty. Laryngoscope. 2009 Feb;119(2):414-8. [PubMed | Full Text | DOI]

\section{The Author(s) 2018.}

This work is licensed under a Creative Commons Attribution 4.0 International License. The images or other third party material in this article are included in the article's Creative Commons license, unless indicated otherwise in the credit line; if the material is not included under the Creative Commons license, users will need to obtain permission from the license holder to reproduce the material. To view a copy of this license, visit http://creativecommons.org/licenses/by/4.0/ 